\title{
DIVERSITY OF DRAGONFLY SPECIES IN THE HAKIKINDA ISLANDS OF MAHAWELI RIVER IN THE GATABE AREA
}

\author{
HIGC Kumara ${ }^{1}$, VAMPK Samarawikrama ${ }^{2}$
}

\begin{abstract}
Hakkinda Islands surrounded by the Mahaweli River, close to the KandyGatambe area is a bio-geographical hotspot in Sri Lanka. However, biogeographical importance of these islands has been overlooked during the last few decades as a result of development projects and wide-ranging human activities. Considering this fact, the President of Sri Lanka declared the Waratenna-Hakkinda geographical region as a conserved/ protected environmental area. According to the rudimentary survey, this protected area can be identified a special habitat to dragonfly species, which biologically comes under the 'insect' category (order- Odonata \& infraorder- Anisoptera). Since the existing literature written on diversity of dragonfly species shows an inadequacy, the main objective of this research is to explore and examine the variation of this particular species inhabited to the research area. This research is guided by QuantitativeDeductive research methodology. Under this methodology, line transects, and quadrate sampling methods have been used for primary data collection. According to the research findings, a total number of 16 dragonfly species belonged to 08 families were identified and both riverine forest and river islands have rich diversity compared with home gardens in the area. Among the available species, $37.5 \%$ are identified to be endemic to the country. Three species, namely, Oriental Green Wing (Neurobasis chinensis), Black-tipped damsel (Vestalis apicalis) and Sri Lanka Ultima gem (Libellago finalis) are identified to be endangered/ vulnerable species. This research concludes that theough there are a high diversity of dragonfly species in the river islands and riverine forest areas, human activities and their irresponsible behaviour have directly and indirectly influenced negatively on dragonfly habitats and their breeding colonies. The research, thus, identified an immediate requirement for a regulatory mechanism to protect this biologically important breeding colony of dragonfly species and their habitats to protect their diversity.
\end{abstract}

${ }^{1}$ Department of Geography, University of Ruhuna-Sri Lanka

${ }^{2}$ Edward \& Christie (Pvt) Ltd. Nugegoda. Sri Lanka

Corresponding Author: HIGC Kumara

chamindakumara03@yahoo.com

Keywords: Hakkinda protected area, Dragonfly species, Diversity, Habitat protection

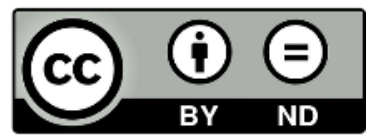

This article is published under the Creative Commons CC-BY-ND License (https://creativecommons.org/licenses/by-nd/4.0/). This license permits use, distribution and reproduction, commercial and non-commercial, provided that the original work is properly cited and is not change anyway. 


\section{INTRODUCTION}

Hakkinda Islands surrounded by the Mahaweli River, close to the Kandy-Gatabe area is a bio-geographical hotspot in Sri Lanka (Samarawickrama, Samarawikrama \& Gunawardhana, 2012). The literature survey of the research identifies a potential 'knowledge gap' in nature of diversity of dragonfly species in the Hakkinda Islands and sounding river bank areas. This research focuses on bridging this 'gap' in prevalent knowledge.

Hakkinda Islands of Mahaweli River There are 20 islands in the Hakkinda Islands complex (see map no 1). These islands together with the Mahaweli River provides a unique and attractive landscape ecological view in this area (see picture no 2 ). These islands and surrounding areas are home to a large number of rare and endemic flora and fauna species of the country. For example, the critically endangered species of fish endemic to Sri Lanka called Green Labeo- Kolagadaya - [Labeo fisheri (Cyprinidae)] (Bănărescu, \& Coad, 1991; de Goonatilake, 2012), which is thought to be extinct from the country has been recently discovered here by Samarawikrama et all (see picture no 1) (Hettiarachchi, 2017; Samarawickrama, Samarawikrama \& Gunawardhana, 2012)

Picture no 1: Very rare and critically endangered species of Hakkinda islands: Green LabeoKolagadaya - (Labeo fisheri) and Farmeria metzgerioides
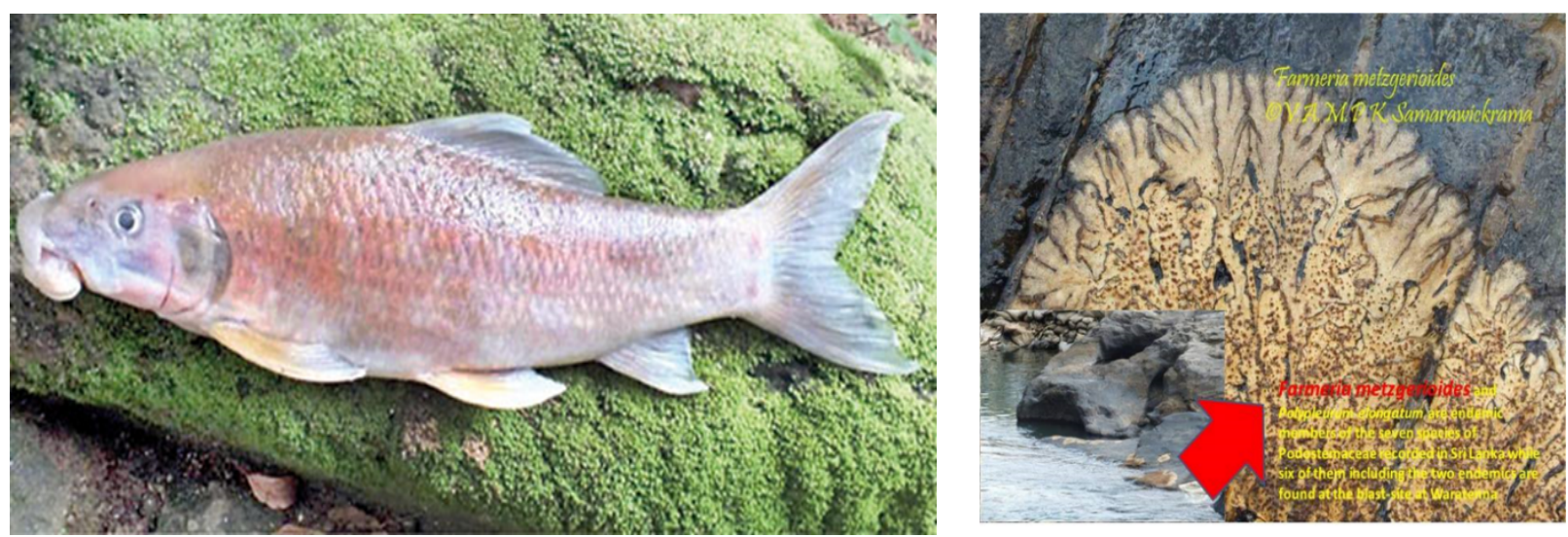

Photographed by VAMPK Samarawikrama

One of the other examples is a very rare flora species here called Farmeria metzgerioides, which has only been recorded in eight other locations in KeralaIndia and Sri Lanka (Yakandawala, 2012). It is listed as a vulnerable species in the world and in Sri Lanka it is recorded only in two locations, namely at Hakkinda in Kandy district and at Haragama in the Central Province (see picture 01) (Kumar et all, 2011; Yakandawala, 2012). The National Aquatic Research and Development Agency (NARA) has also researched on the biodiversity of this area and according to that, Hakkinda islands have been identified as biodiversity hotspot which provide habitats for many endemic and rare aquatic species of Sri Lanka (Sunday Times, 2016).However, biogeographical importance of Hakkinda islands has been gradually ignored during the last few decades as a result of development projects and different types of human activities (Mendis, 2017). A small group of activists, including researchers and environmentalists has continually struggled for six years against these human activities leading to environmental degradation of Hikkind islands. 
As a result, the President of Sri Lanka declared the Waratenna-Hakkinda area in Kandy District in the Central Province as a protected environmental area under Section $24 \mathrm{C}$ of the National Environmental Act (NEA), permitting, regulating and prohibiting certain activities in this area under Section 24D of the NEA. This order is officially published in the Gazette Extraordinary No; 2024/06 of 19.06.2017 (Hettiarachchi, 25.06. 2017).

\section{Dragonfly Species}

Biologically, dragonfly species and damselfly species come under 'insect' category (order- Odonata \& infraorderAnisoptera) and members of the order Odonata belong to one of two suborders: the Zygoptera (damselflies) and the Anisoptera (dragonflies) (Van der Poorten \& Conniff, 2012). Adult dragonflies have multifaceted eyes, transparent wings and a lengthened body (Suhling et all, 2005). About 3000 dragonfly species have been discovered in the world and most of their habitats are located in tropical areas (Nóbrega \& De Marco, 2011). As described by Van der Poorten, \& Conniff (2012), a total of 121 dragonfly species are discovered in Sri Lanka and 48 species of them are endemic to the country (Van der Poorten, \& Conniff (2012). According to Bedjanič et all (2014), there are 124 dragonfly species (120 described +04 undescribed) in Sri Lanka and among them 52 (48 described +4 undescribed) species are endemic to the island, as well, 9 species are identified as sub species (Bedjanič et all, 20140, which means $42 \%$ of dragonfly species of the total species discovered in the country is endemic to Sri Lanka.

Sri Lanka and South India share similar bio-geographical conditions and as a result, most of dragonfly species are common to both geographical zones. Since members of some odonate fauna are endemic to Sri Lanka, it is geographically separated from
Indian sub-continent. For example, Chlorocyphidae (4 species), Euphaeidae (1 species), Protoneuridae (6 species), Platystictidae (18 species), Corduliidae (2 species), and Gomphidae (all except for 3 species) are seen only in this island. Some of the endemic species seem to be taxonomically isolated (e.g. Sinhalestes orientalis Cyclogomphus gynostylus and Microgomphus wijaya) (Van der Poorten \& Conniff, 2012).

Ecosystems such as wetlands, forests, grasslands, agricultural lands and coastal forests are identified special habitats of dragonfly species (Fonseka, 2000) and water pollution and forest degradation are key factors threatening their habitats. Increasing human population and booming agricultural activities lead to forest degradation and water pollution in Sri Lanka, thus, it has gravely affected available dragonfly habitats located on water sources and forest ecosystems (Van der Poorten \& Conniff, 2012; Bedjanič et all, 2014). Even though researchers have considerably attended to study dragonfly species of Sri Lanka, still there is a gap in the prevalent knowledge about dragonfly species in Sri Lanka. For example, there are no records about 5 species among the recorded dragonfly species of Sri Lanka for the last 50 years, no photographic records on 8 species in Sri Lanka, photographs of living animals on 3 species are unavailable, only a single sex is described among 8 species, larval stages are unknown for about 80 species, and adult and larval habitat preference are still unknown (Sumanapala, 2014). The Hakkinda islands of Mahaweli River is identified a special habitat for aquatic species as well as species living in the watery ecosystems. Scholars have not paid enough attention on analysing the diversity of Dragonfly species at Hakkinda islands and its associated ecosystems. Thus, this research focuses on bridging the prevalent gap in the available knowledge about dragonfly species. 
Map 01: Location Map of Hakkinda - a Protected Environmental Area, Kandy.
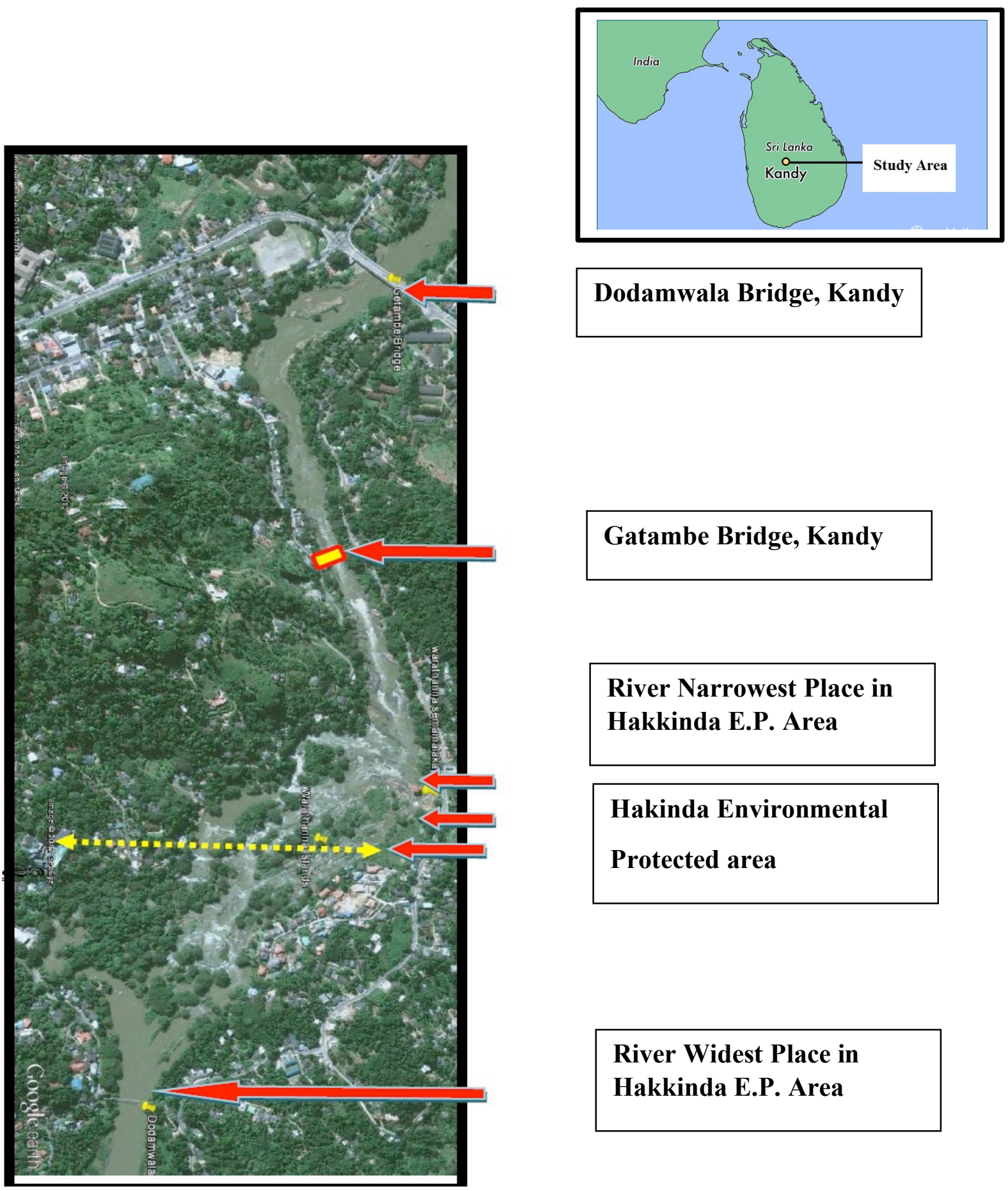

Dodamwala Bridge, Kandy

Gatambe Bridge, Kandy

River Narrowest Place in Hakkinda E.P. Area

Hakinda Environmental

Protected area

River Widest Place in Hakkinda E.P. Area 
Journal of Social Sciences and Humanities Review (JSSHR)

Vol. 3, Issue 2 (71-84)

(C) Author(s) June 2018

Original Article

ISSN: 2279-3933

Picture 02: View of Hatkinda Islands
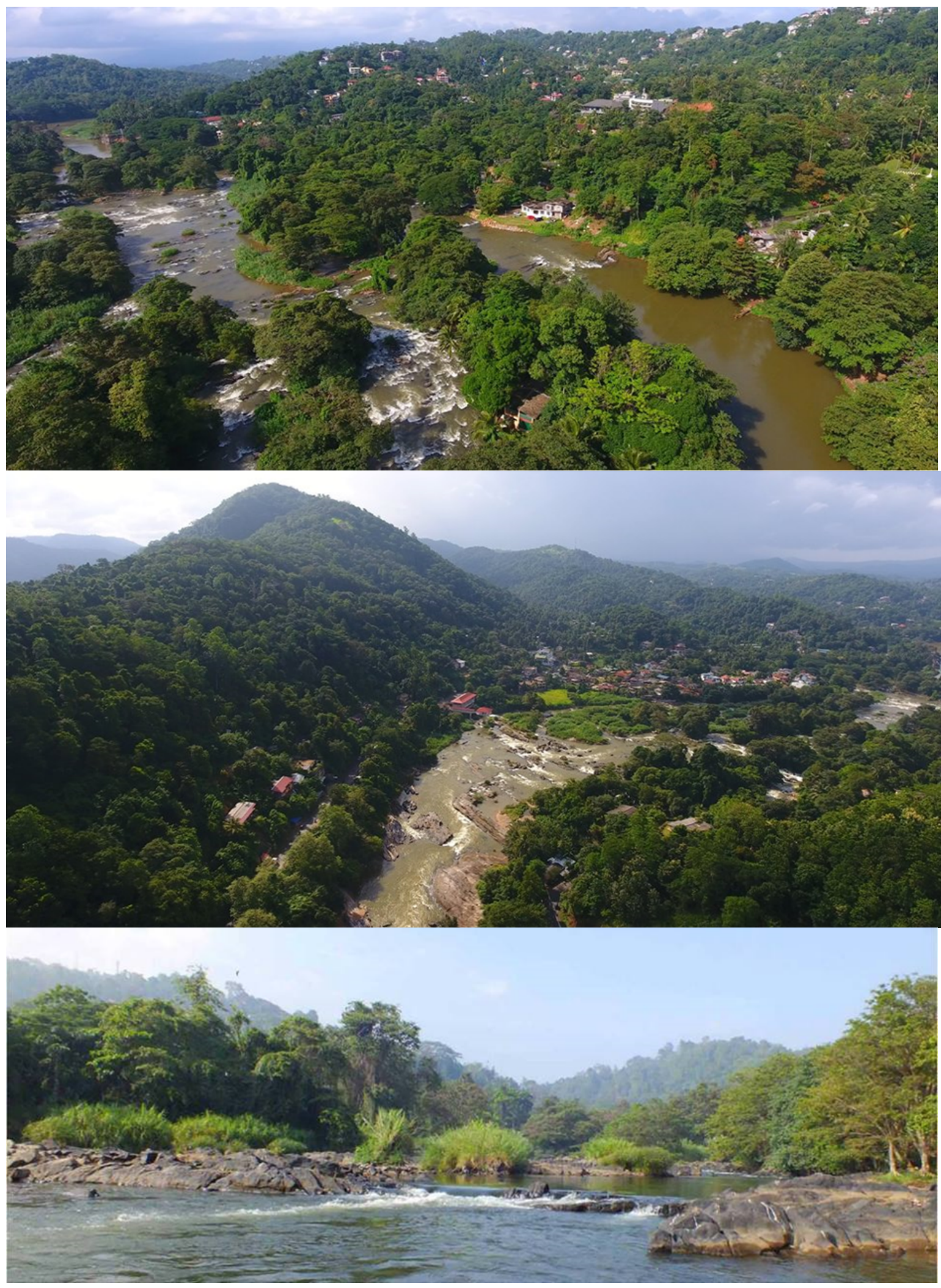

Photographed by VAMPK Samarawikrama 


\section{RESEARCH OBJECTIVES}

The main objective of this research is to examine 'diversity of dragonfly species in the Hakkinda Islands of Mahaweli River in Gatabe area'. Under this, there are two specific research objectives.

i. To prepare an information table about dragonfly species found in the Hakkinda Islands of Mahaweli River in Gatabe area.

ii. To identify inhabiting dragonfly species under the categories: 'vulnerable species', 'common species', 'endemic species' and 'endangered species'.

\section{MATERIALS AND METHODS}

\section{Identify the Knowledge Gap}

A literature and pilot survey have been conducted to identify the potential knowledge gap and research questions. A total of 04 days from 10 to 15 April 2017 [10 hrs per day (during day and night)] were spent on the particular field to identify the suitability of this area for the research.

\section{Research Methods}

i. A total of 20 days ( $12 \mathrm{hrs}$ per day both day and night) were spent on fieldwork during May and July 2017. ii. Visual encounter survey methods were used associating with general area surveys, line transects and quadrate sampling methods $(10 \mathrm{~m} \times 10 \mathrm{~m})$.

iii. Four quadrate samples and four line transects are randomly taken from each different habitat types.

iv. All microhabitats such as water bodies, under rocks, logs and decaying vegetation of riverbanks and trees and bushes had been considered while selecting sample plots.

v. All captured specimens were examined carefully and recorded before being released at their capture site without injury.

vi. No specimens were collected, transported or deposited from the outside the forest.

vii. Threat criteria had be given according to IUCNSL \& MENR (2012).

\section{RESULT AND DISCUSSION}

Three different habitats of dragonfly species are identified in the research field such as; (1) 'River Island Habitat', (2) 'Riverine Forest Habitat' and (3) 'Home Garden Habitat' within the Hakkinda sensitive environmental area (see picture no 03). 4 line transects $(50 \mathrm{~m})$ and 4 quadrate samples $(10 \mathrm{~m} \times 10 \mathrm{~m})$ were carried out to each habitat to identify the diversity of the species (altogether 12 line transects and 12 quadrate sample have done to collect data). 
Journal of Social Sciences and Humanities Review (JSSHR)

Vol. 3, Issue 2 (71-84)

(C) Author(s) June 2018

\section{Original Article}

ISSN: 2279-3933

Picture 3. Different types of dragonfly species habitats within the research field

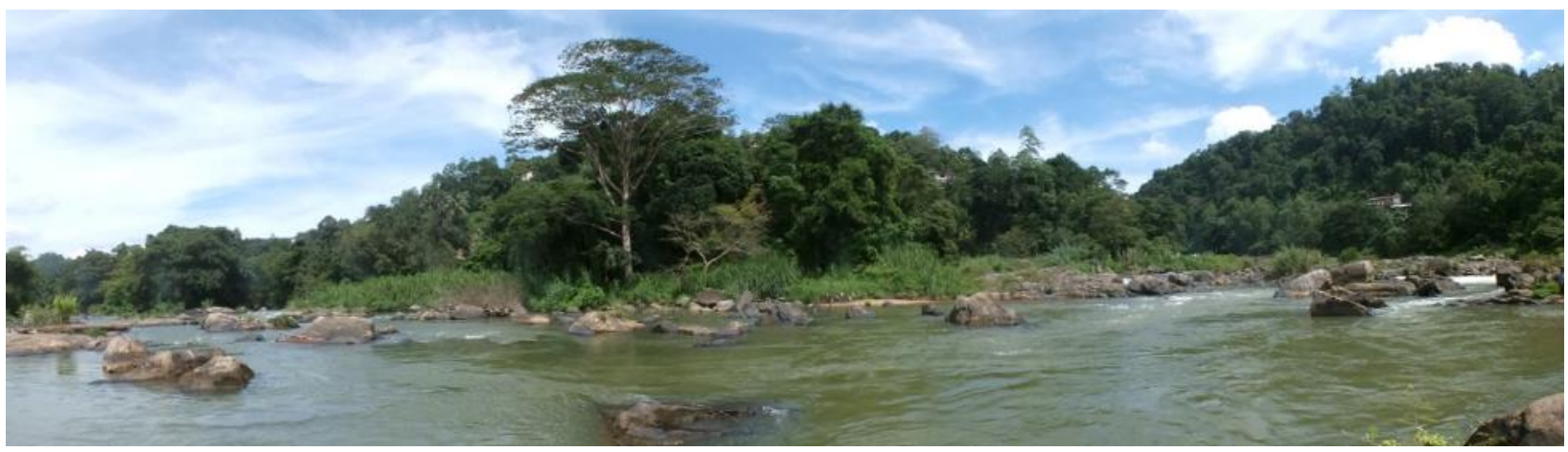

River Island Habitat, Hakkinda Environmental Sensitive Area.

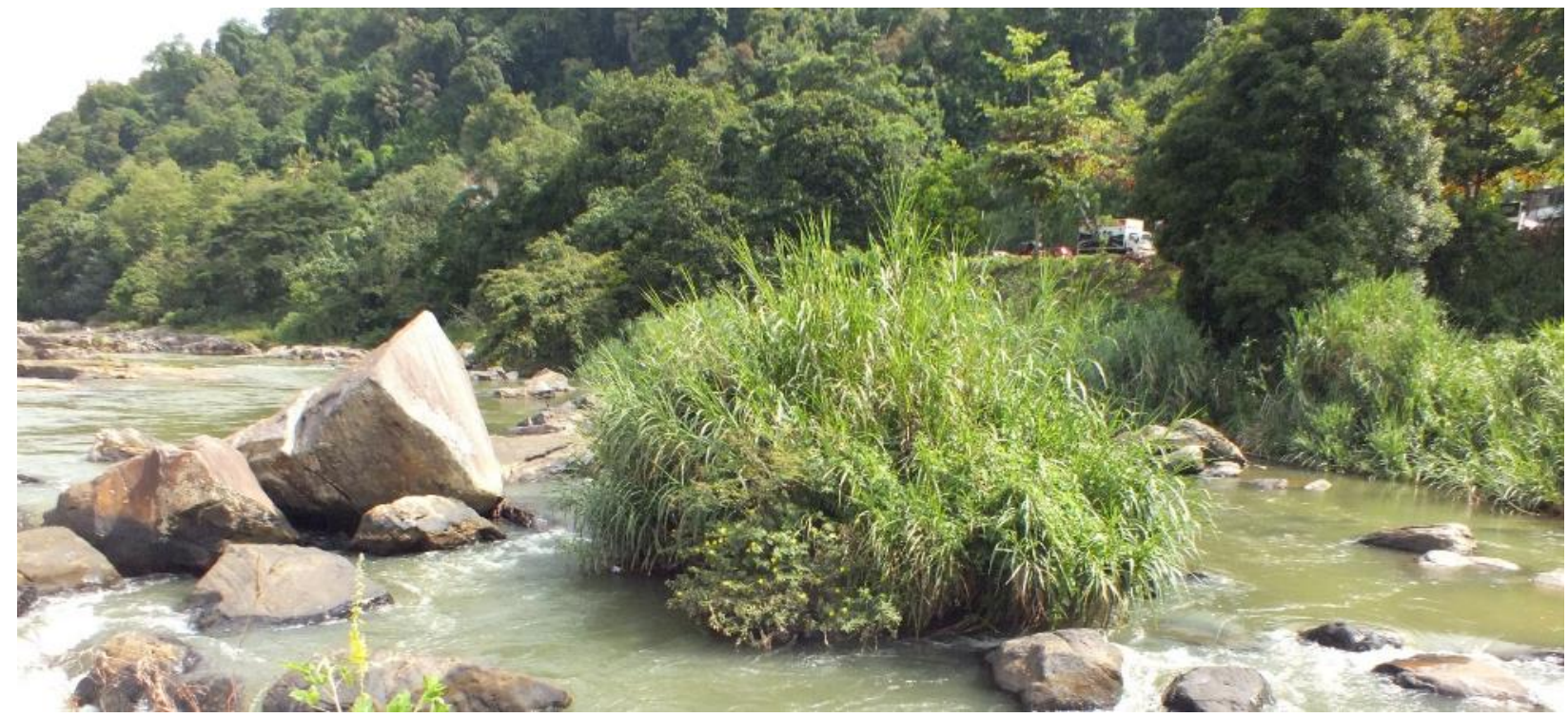

Riverine forest Habitat, Hakkinda Environmental Sensitive Area.

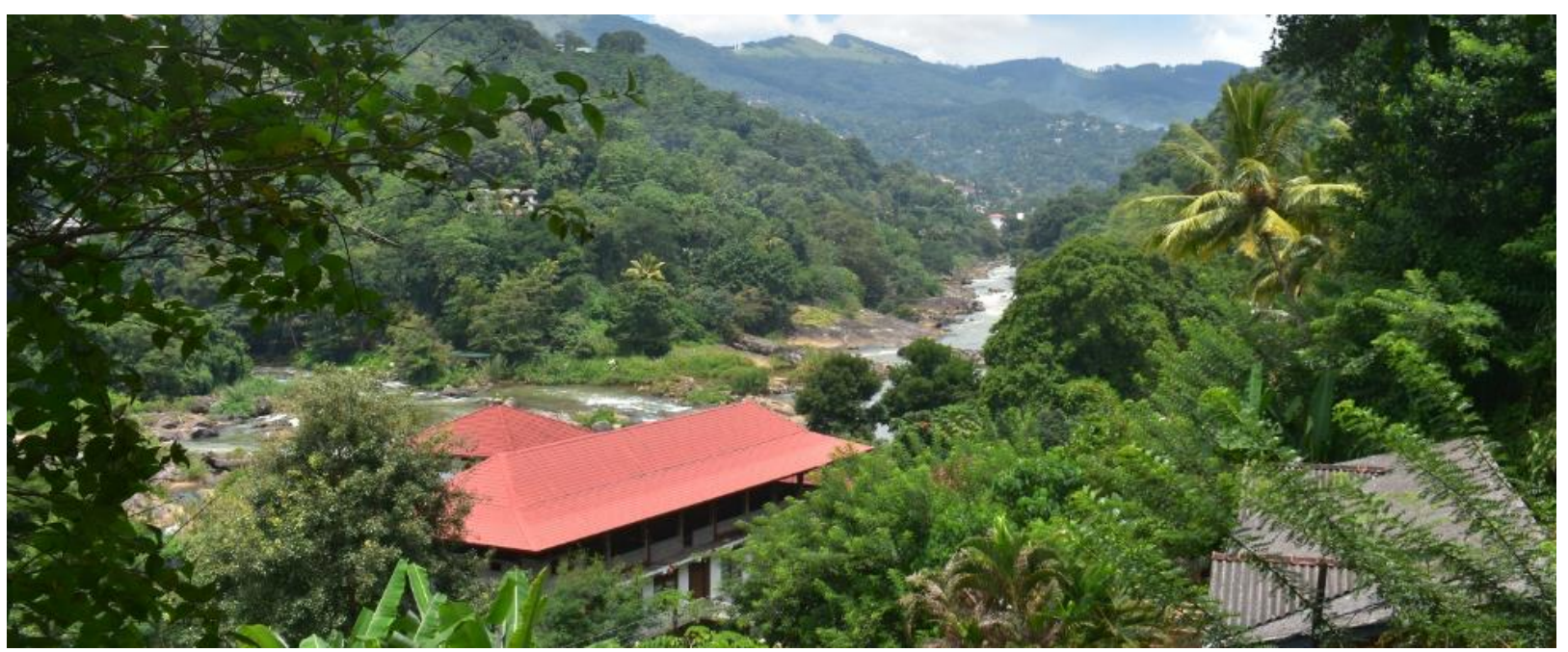

Home garden Habitat, Hakkinda Environmental Sensitive Area.

Photographed by VAMPK Samarawikrama 
Table 1: Summery of dragonfly species diversity [Zygoptera (damselflies) and the nisoptera (dragonflies)] in the Hakkinda protected area

\begin{tabular}{|c|c|c|c|c|c|c|}
\hline Family & Species & $\begin{array}{l}\text { Common } \\
\text { Name }\end{array}$ & $\begin{array}{l}\text { Conser- } \\
\text {-vation } \\
\text { status }\end{array}$ & $\begin{array}{l}\text { Riverine } \\
\text { forest }\end{array}$ & $\begin{array}{l}\text { Home } \\
\text { Garden }\end{array}$ & $\begin{array}{l}\text { River } \\
\text { Islands }\end{array}$ \\
\hline \multirow[t]{2}{*}{ Calopterygidae } & $\begin{array}{l}\text { Neurobasis } \\
\text { chinensis }\end{array}$ & $\begin{array}{l}\text { Oriental Green } \\
\text { wing }\end{array}$ & VU & $\sqrt{ }$ & $\sqrt{ }$ & $\sqrt{ }$ \\
\hline & Vestalis apicalis & $\begin{array}{l}\text { Black-tiped } \\
\text { demoisele }\end{array}$ & VU & $\sqrt{ }$ & - & $\sqrt{ }$ \\
\hline \multirow[t]{2}{*}{ Chlorocyphidae } & Libellago greeni & $\begin{array}{l}\text { Sri Lanka } \\
\text { Green,s gem }\end{array}$ & $\mathrm{E}, \mathrm{EN}$ & $\sqrt{ }$ & $\sqrt{ }$ & $\sqrt{ }$ \\
\hline & Libellago finalis & $\begin{array}{l}\text { Sri Lanka } \\
\text { Ultima gem }\end{array}$ & $\mathrm{E}, \mathrm{VU}$ & $\sqrt{ }$ & - & $\sqrt{ }$ \\
\hline Euphaeidae & $\begin{array}{l}\text { Euphaea } \\
\text { splendens }\end{array}$ & $\begin{array}{l}\text { Sri Lanka } \\
\text { Shining } \\
\text { Groosmerwing }\end{array}$ & $\mathrm{E}$ & $\sqrt{ }$ & $\sqrt{ }$ & $\sqrt{ }$ \\
\hline Coenagrionidae & $\begin{array}{l}\text { Pseudagrion } \\
\text { rubriceps }\end{array}$ & $\begin{array}{l}\text { Sri lanka } \\
\text { orange-faced } \\
\text { sprite }\end{array}$ & $\mathrm{E}$ & $\sqrt{ }$ & - & $\sqrt{ }$ \\
\hline Platystictidae & $\begin{array}{l}\text { Copera } \\
\text { marginipes }\end{array}$ & $\begin{array}{l}\text { Yellow } \\
\text { fetherwing }\end{array}$ & & $\sqrt{ }$ & - & - \\
\hline Protoneuridae & $\begin{array}{l}\text { Prodasineura } \\
\text { sita }\end{array}$ & $\begin{array}{l}\text { Sri Lanka } \\
\text { Stripe-headed } \\
\text { Threadtail }\end{array}$ & $\mathrm{E}$ & $\sqrt{ }$ & - & $\sqrt{ }$ \\
\hline \multirow[t]{7}{*}{ Libellulidae } & Trithemis aurora & $\begin{array}{l}\text { Dawn } \\
\text { Dropwing }\end{array}$ & & $\sqrt{ }$ & - & $\sqrt{ }$ \\
\hline & $\begin{array}{l}\text { Bradinopyga } \\
\text { geminata }\end{array}$ & $\begin{array}{l}\text { Indian } \\
\text { Rockduweler }\end{array}$ & & $\sqrt{ }$ & $\sqrt{ }$ & $\sqrt{ }$ \\
\hline & Trithemis festiva & $\begin{array}{l}\text { indigo } \\
\text { dropwing }\end{array}$ & & $\sqrt{ }$ & - & $\sqrt{ }$ \\
\hline & $\begin{array}{l}\text { Brachythemis } \\
\text { contaminata }\end{array}$ & $\begin{array}{l}\text { ornge-wing } \\
\text { groundline }\end{array}$ & & $\sqrt{ }$ & - & $\sqrt{ }$ \\
\hline & $\begin{array}{l}\text { Orthetrum } \\
\text { sabina }\end{array}$ & Green skimer & & - & - & $\sqrt{ }$ \\
\hline & $\begin{array}{l}\text { Orthetrum } \\
\text { pruinosum }\end{array}$ & pink skimer & & $\sqrt{ }$ & $\sqrt{ }$ & $\sqrt{ }$ \\
\hline & $\begin{array}{l}\text { Orthetrum } \\
\text { glaucum }\end{array}$ & $\begin{array}{l}\text { Asian } \\
\text { skiminer }\end{array}$ & & $\sqrt{ }$ & $\sqrt{ }$ & $\sqrt{ }$ \\
\hline Gomphidae & $\begin{array}{l}\text { Paragomphus } \\
\text { henryi }\end{array}$ & $\begin{array}{l}\text { Sri Lanka } \\
\text { Brook } \\
\text { Hooktail }\end{array}$ & $\mathrm{E}$ & - & $\sqrt{ }$ & - \\
\hline Total 08 & 16 & & & 14 & 07 & 14 \\
\hline
\end{tabular}


According to the research findings of this study, a total of 16 dragonfly species which belongs to 08 families are identified and it is observed that both riverine forest and river islands are richer in diversity than homegarderns (see table no 1). Among the available species, $37.5 \%$ are endemic species to the country. Three species, namely, Oriental Green Wing (Neurobasis chinensis), Black-tipped damsel (Vestalis apicalis) and Sri Lanka Ultima gem (Libellago finalis) are vulnerable species.

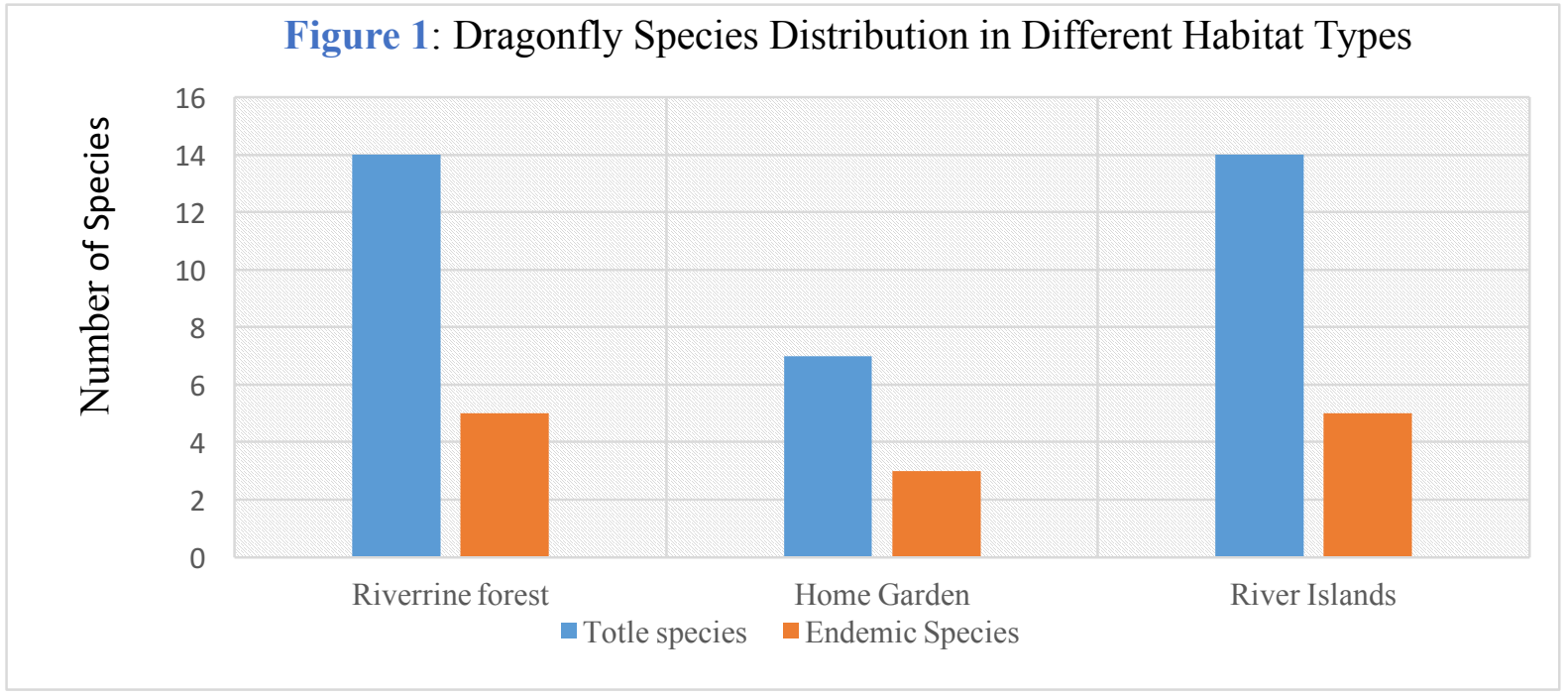

Among the total amount of species, one endemic species [Sri Lanka Green's Gem (Libellago greeni)] is recognized an endanger species. As well, Sri Lanka Brook Hooktail (Paragomphus henryi) is recorded only in the home garden area.

\section{CONCLUSION}

Protected areas of the Hakkida Islands complex located in the Mahaweli River close to Gatabe-Peradeniya are a biological and geographical hotspot in Sri Lanka. Diversity of dragonfly species is comparatively high in this area; especially in riverine forest and river island habitats.
A considerable numbers of endemic, vulnerable and endangered dragonfly species are recorded within these habitats. Breeding colonies of dragonfly species are located along the riverbanks and peripheral areas of the islands. Thus, this island complex is an environmental sensitive and biological valuable areas. Human activities and their irresponsible behaviour have directly/indirectly negatively influenced on these sensitive breading colonies. Therefore, a strong and immediate mechanism and regulations to protect these biologically valuable breeding colonies of dragonfly species and their habitats are essential to protect their diversity. 
Journal of Social Sciences and Humanities Review (JSSHR)

Vol. 3, Issue 2 (71-84)

(C) Author(s) June 2018

\section{Original Article}

ISSN: 2279-3933

Picture 03: Dragonfly species of Hakkinda protected areas
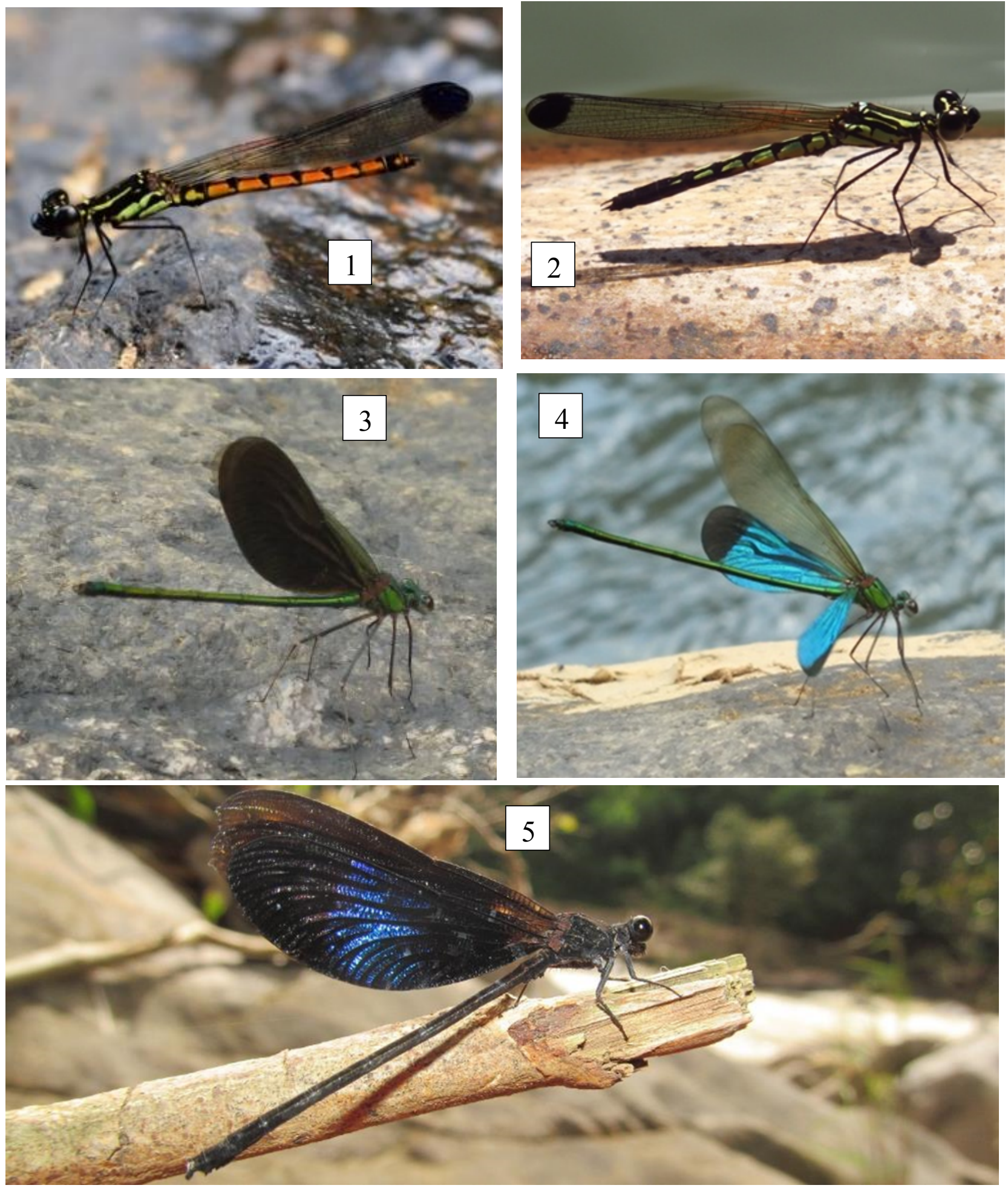

1. Green's gem (Libellago greeni)-Endemic Species, Hakkinda Island Area.

2. Ultima gem (Libellago finalis)-Endemic Species, Hakkinda Island Area.

3. Oriental Green wing (Neurobasis chinensis), Hakkinda Island Area.

4. Black-tipped demoiselle (Vestalis apicalis), Hakkinda Riverine forest Area.

5. Shining Groosmerwing (Euphaea splendens)-Endemic Species, Hakkinda Riverine forest Area 
Journal of Social Sciences and Humanities Review (JSSHR)

Vol. 3, Issue 2 (71-84)

(C) Author(s) June 2018

\section{Original Article}
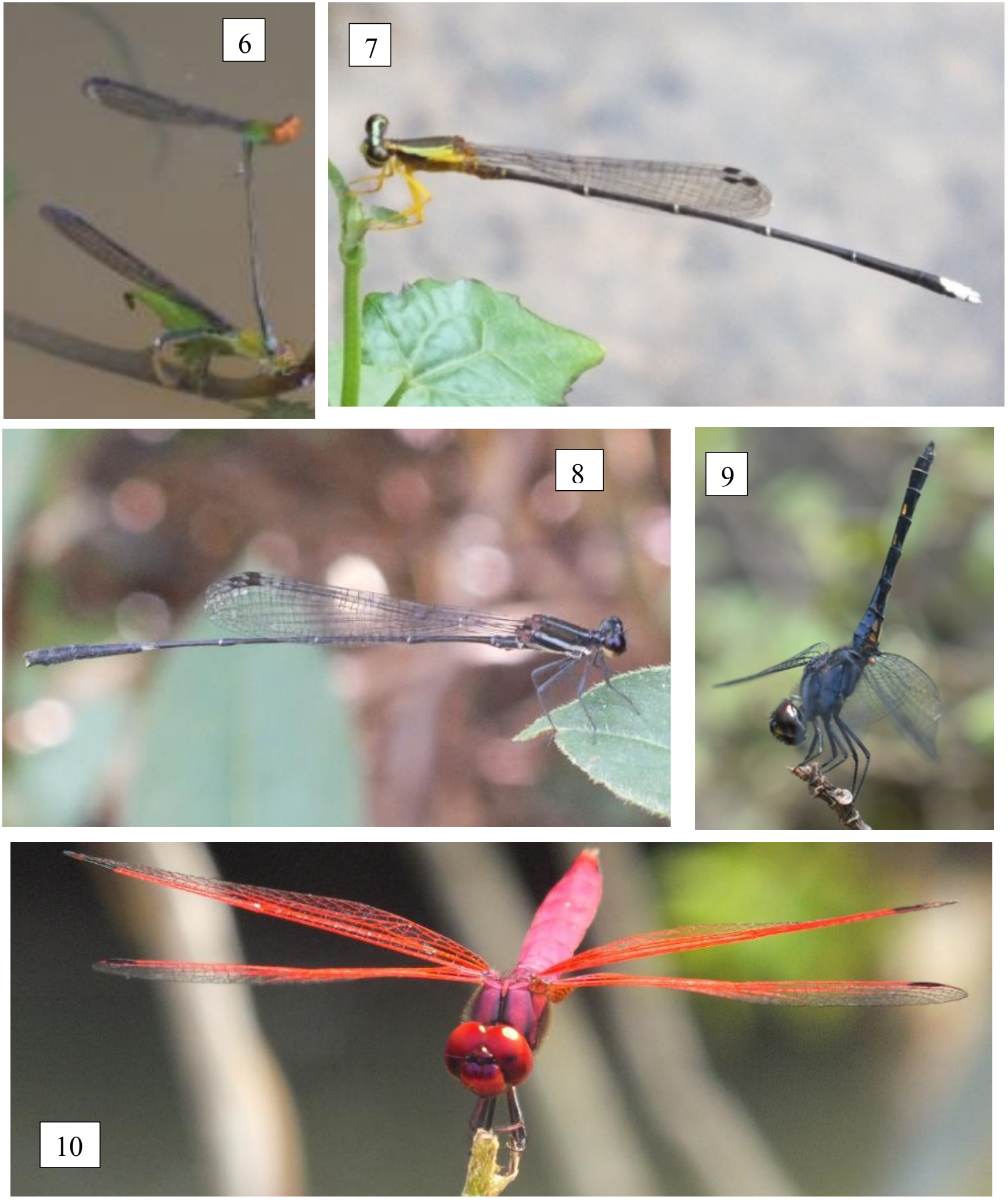

6. Sri Lanka orange-faced sprite (Pseudagrion rubriceps)-Endemic Species, Hakkinda Riverine Forest Area

7. Rimmed or Yellow featherwing (Copera marginipes) Riverine forest

8. Sri Lanka Stripe-headed Threadtail (Prodasineura sita)-Endemic Species, River Island

9. Indigo dropwing (Trithemis festiva)-River Island Area.

10. Dawn Dropwing (Trithemis aurora)-Riverrine Habitat. 

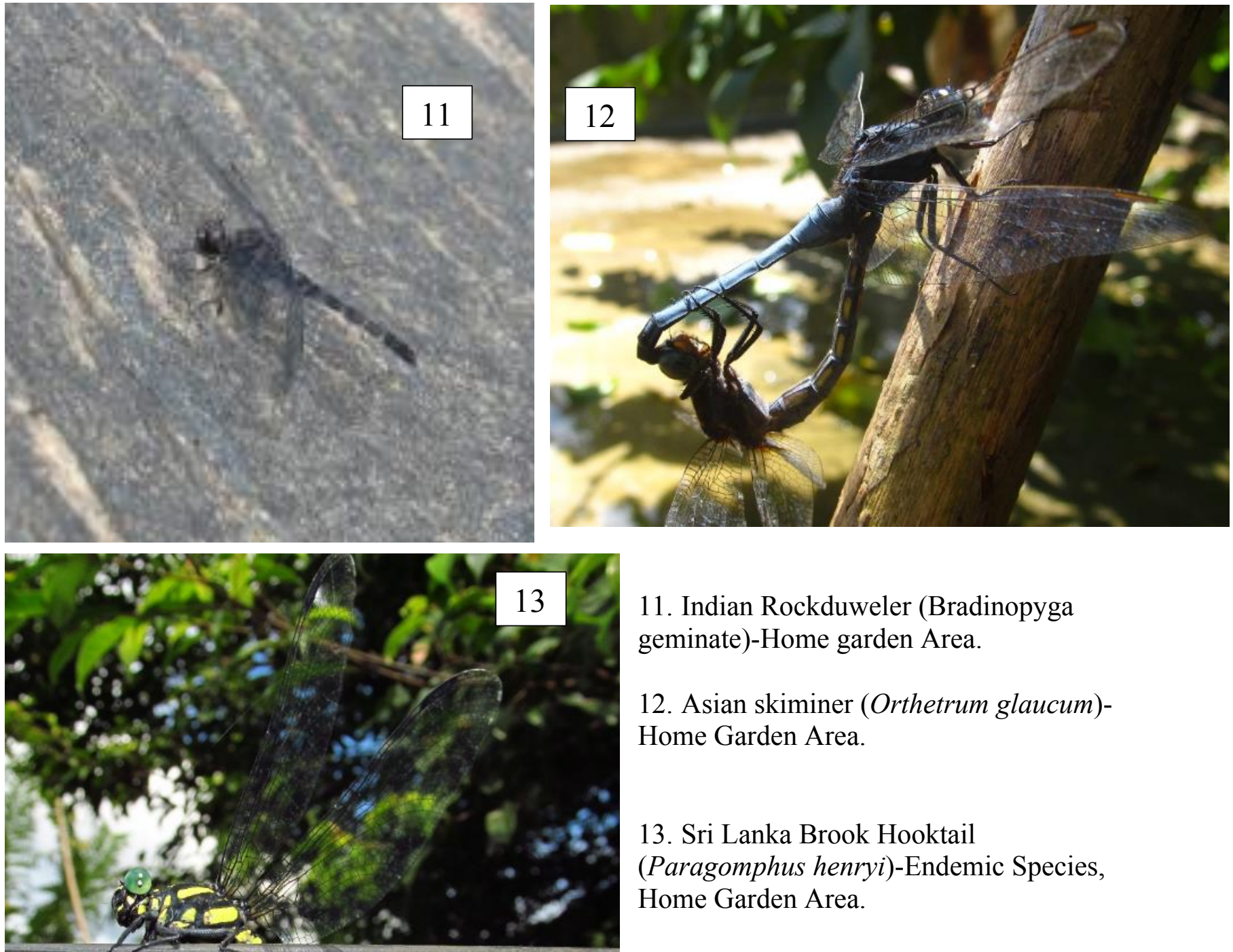

11. Indian Rockduweler (Bradinopyga geminate)-Home garden Area.

12. Asian skiminer (Orthetrum glaucum)Home Garden Area.

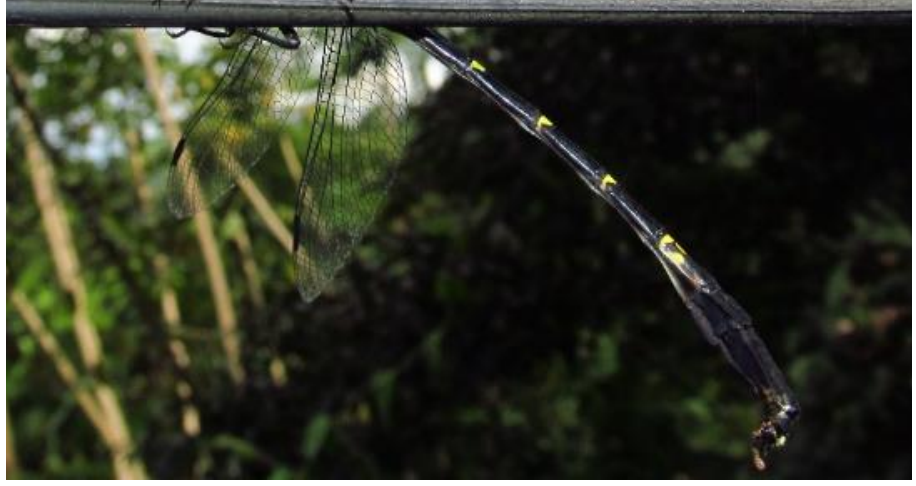

13. Sri Lanka Brook Hooktail

(Paragomphus henryi)-Endemic Species, Home Garden Area.

\section{REFERENCES}

Gunawardena, J. P. W., Fonseka, K. T., \& Jayasinghe, G. (2001). Small

Alston, A. H. G. (1929). The Kandy Flora.

Peradeniya, Sri Lanka: Agricultural Department.

Amerasinghe, F. P., Konradsen, F., Van irrigation tanks as a source of malaria mosquito vectors: A study in northcentral Sri Lanka (Vol. 57).Colombo, Sri Lanka: IWMI.

Der Hoek, W., Amerasinghe, P. H., 
Anderson, R. C. (2009). Do dragonflies migrate across the western Indian Ocean?. Journal of Tropical Ecology, 25(04), 347-358.

Bambaradeniya, C. N. (2006). The Fauna of Sri Lanka: Status of Taxonomy, Research, and Conservation. Colombo. Sri Lanka: IUCN.

Bănărescu, P., \& Coad, B. W. (1991). Cyprinids of Eurasia. Cyprinid fishes. Systematics, biology and exploitation, 127-155. NY, USA: Springer

Bedjanič, M., Conniff, K., \& de Silva Wijeyeratne, G. (2007). A photographic guide to the dragonflies of Sri Lanka. Colombo, Sri Lanka: Jetwing Eco Holidays.

Bedjanič, M. (2012). On the synonymy of three endemic dragonfly species from Sri Lanka (Zygoptera: Platystictidae, Protoneuridae). Notulae odonatologicae, 7(9), 77-88.

Bedjanič, M., Conniff, K., Van der Poorten, N., \& Šalamun, A. (2014). Dragonfly fauna of Sri Lanka: distribution and biology, with threat status of its endemics. Sofia, Bulgaria: Pensoft.

de Goonatilake, A S. (2012) The

Taxonomy and Conservation Status of the Freshwater Fishes in Sri Lanka. The National Red List 2012 of Sri Lanka. Colombo, Sri Lanka: Biodiversity Secretariat, Ministry of Environment Sri Lanka

Fonseka, T. D. (2000). Dragonflies of Sri Lanka. WHT Publications.

Gunawardene, N. R., Daniels, D. A., Gunatilleke, I. A. U. N., Gunatilleke, C. V. S., Karunakaran, P. V., Nayak, G. K., Vasanthy, G. (2007). A brief overview of the Western Ghats-Sri
Lanka biodiversity hotspot. Current science, 93(11), 1567-1572.

Hettiarachchi, K (25.06. 2017) WaratennaHakkinda declared an EPA after long fought battle by environmentalists. Sunday Times. Retrieved from http://www.sundaytimes.1k/170625/ne ws/waratenna-hakkinda-declared-anepa-after-long-fought-battle-byenvironmentalists-246593.html.

Kumar, R. B., Anitha, K., Watve, A., Mani, S., Rehel, S., \& Arisdason, W. (2011). The status and distribution of aquatic plants of the Western Ghats. $S$. Molur, KG Smith, BA Daniel, and WRT Darwall [compilers], The status and distribution of freshwater biodiversity in the Western Ghats, India, 49-62.

Mendis, R (21.06.2017) WaratennaHakkinda now a protected area. Ceylon Today. Retrieved from http://www.ceylontoday.lk/print20170 401CT20170630.php?id=23775

Nóbrega, C. C., \& De Marco, P. (2011). Unprotecting the rare species: a nichebased gap analysis for odonates in a core Cerrado area. Diversity and Distributions, 17(3), 491-505.

Tiple, A. D., Paunikar, S., \& Talmale, S. S. (2012). Dragonflies and Damselflies (Odonata: Insecta) of Tropical Forest Research Institute, Jabalpur, Madhya Pradesh, central India. Journal of Threatened Taxa, 4(4), 2529-2533.

Nóbrega, C. C., \& De Marco, P. (2011). Unprotecting the rare species: a nichebased gap analysis for odonates in a core Cerrado area. Diversity and Distributions, 17(3), 491-505. 
Samarawickrama, VAMPK;

Samarawikrama, DRNS \&

Gunawardhana, J (2012) New site record of Gadaya (Labio fisheri) from

Warathenna, Hakkinda, Central province, Sri Lanka. 18th Annual

Scientific Sessions. Colombo, Sri

Lanka: Proceedings of 18th Annual

Scientific Sessions of Sri Lankan

Association for Fisheries and Aquatic

Resources (SLAFAR).

Suhling, F., Sahlén, G., Kasperski, J., \& Gaedecke, D. (2005). Behavioural and life history traits in temporary and perennial waters: comparisons among three pairs of sibling dragonfly species. Oikos, 108(3), 609-617.

Sumanapala, AP (2014) Dragonflies of Sri Lanka An Introduction to Diversity, Ecology and Conservation. Retrieved from.

http://www.bcssl.lk/lectures/BCSSLLec9-Dragonflies-of-Sri\%20Lanka-anIntroduction-to-Diversity-Ecology-\&Conservation-2014-Nov Amila.pdf

Sunday Times (30.10.2016) Stop the environment degradation. Retrieved from http://www.sundaytimes.lk/161030/ne ws/stop-the-environment-degradation$\underline{215385 . h t m l}$

Van der Poorten, N., Conniff, K. (2012). The taxonomy and conservation status of the dragonfly fauna (Insecta: Odonata) of Sri Lanka. The National Red List 2012 of Sri Lanka. Colombo, Sri Lanka: Biodiversity Secretariat, Ministry of Environment Sri Lanka.

Yakandawala, D. (2012). Present status of fresh water aquatic flora in Sri Lanka. The National Red List 2012 of Sri

Lanka. Colombo, Sri Lanka:
Biodiversity Secretariat, Ministry of Environment Sri Lanka 